\title{
Koncepcja Heartlandu Halforda Mackindera
}

\author{
Halford Mackinder's Heartland concept
}

\author{
PIOTR EBERHARDT \\ Instytut Geografii i Przestrzennego Zagospodarowania im. S. Leszczyckiego PAN, \\ 00-818 Warszawa, ul. Twarda 51/55; p.ebe@twarda.pan.pl
}

Zarys treści. W artykule przedstawiono osiągnięcia twórcze wybitnego geografa brytyjskiego Halforda Johna Mackindera. Główną uwagę skoncentrowano na prezentacji jego koncepcji geopolitycznej dotyczącej Heartlandu („serca kontynentu”). Miała ona duże znaczenie teoretyczne i poznawcze, a następnie wywołała głośną polemikę naukową. Po zreferowaniu jej treści i walorów merytorycznych starano się ukazać skalę jej adekwatności politycznej.

Słowa kluczowe: Mackinder, geopolityka, Heartland.

\section{Wprowadzenie}

Brytyjskiego geografa Halforda Johna Mackindera zalicza się do czołowych prekursorów światowej geopolityki. Uważa się go powszechnie - obok Friedricha Ratzla, Rudolfa Kjelléna i Karla Haushofera ${ }^{1}$ - za jednego z twórców tej nowej dziedziny wiedzy. Wykorzystuje ona dorobek geografii do opisania i wyjaśnienia zjawisk i procesów politycznych. Budzi nieustannie liczne zastrzeżenia natury formalnej, metodycznej i merytorycznej. Pomimo tych częściowo uzasadnionych obiekcji geopolityka stała się jedną z najbardziej głośnych i popularnych dyscyplin naukowych. Dzieła wymienionych badaczy i ich licznych następców stały się podstawą różnorodnych rozważań, idei, projektów i koncepcji politycznych, których punktem wyjścia jest zawsze konkretna przestrzeń geograficzna.

W ramach geopolityki powstało wiele nowych pojęć bardziej lub mniej ścisłych, które weszły w obieg naukowy i są ogólnie znane. Do takich pojęć należy Heartland („serce kontynentu”). Jest ono powszechnie stosowane nie tylko

\footnotetext{
${ }^{1}$ Informacje o koncepcjach geopolitycznych Haushofera zawarte są we wcześniejszym opracowaniu autora (Eberhardt, 2009).
} 
przez geopolityków, ale również przez geografów ${ }^{2}$. Niekwestionowanym propagatorem tego terminu był Mackinder. Mimo że nie był jego pomysłodawcą ${ }^{3}$, był jednak autorem całej koncepcji związanej z tym dość trudnym do zdefiniowania pojęciem, odniesionym do wyraźnie wyodrębnionego terytorium na ziemi. Mackinder przekonująco uzasadniał, że panowanie nad północną, centralną i wschodnią częścią kontynentu euroazjatyckiego stanowi podstawowy warunek do politycznej dominacji nad światem. Sformułowanie tej hipotezy, a zwłaszcza jej udowodnienie wymagało dużej inwencji twórczej. Dzięki wyjątkowej sprawności umysłowej, połączonej z erudycją i zasobem trudnych do obalenia argumentów Mackinder sprostał temu zadaniu. Niestety występował w jego rozumowaniu element demagogii i retoryki. Dzięki predyspozycjom intelektualnym i bezkrytycznej wierze we własne możliwości twórcze mogła powstać nowatorska koncepcja teoretyczna, którą trudno uzasadnić, ale też niełatwo zanegować. W okresie gdy Mackinder ogłosił swoją koncepcję, decydującą rolę odgrywało panowanie na morzach i zdobywanie kolonii zamorskich. To było koniecznym warunkiem hegemonii politycznej i siły ekonomicznej. Wykazanie, że przyszłość polityczna świata wiązać się będzie z potęgą kontynentalną, było wówczas dość abstrakcyjne - dodatkowo jeszcze dlatego, że autorem tej odważnej projekcji był Brytyjczyk.

Minęło już około stu lat od momentu ogłoszenia i opublikowania dzieła, w którym zawarto koncepcje związane z pojęciem Heartlandu. Pomimo upływu czasu i zmieniających się uwarunkowań demograficznych, politycznych i społecznych jest ono stale obiektem polemik i dyskusji naukowych. Ma swoich licznych zarówno zwolenników, jak i konsekwentnych przeciwników. Poglądy Mackindera są uznawane przez jego apologetów za oczywiste i ponadczasowe. Obok fascynacji spotkały się jednak również z miażdżącą krytyką, odbierającą im wszelkie walory obiektywności i naukowości. Niekończące się spory na ten temat trwają wśród uczonych anglosaskich i rosyjskich. Ci drudzy starają się zazwyczaj uzasadnić słuszność jego hipotez naukowych ${ }^{4}$. Na Zachodzie prace tego angielskiego uczonego oceniane są raczej krytycznie. Traktowane są jako mało ścisłe, przesiąknięte skrajnym determinizmem geograficznym i woluntaryzmem. Zwłaszcza jest to widoczne w pracach geografów o poglądach lewicowych i liberalnych, takich jak C. Flint (2008, s. 50) i M. Blacksell (2008, s. 128).

Opracowania i koncepcje Mackindera są wśród polskich geografów stosunkowo mało znane. W okresie powojennym traktowano je jako wizje o cha-

\footnotetext{
${ }^{2}$ Termin Heartland, którego Mackinder we wcześniejszych swoich pracach używał w formie heart-land może być przetłumaczony z języka angielskiego na polski dosłownie mniej lub bardziej ściśle (serce lądu, serce kontynentu, obszar rdzeniowy, obszar centralny, rdzeń kontynentu, kraj rdzeniowy, strefa centralna, strefa rdzeniowa, itp.). Za wieloma autorami przyjęto polski odpowiednik „serce kontynentu”.

${ }^{3}$ Pierwszym badaczem, który użył terminu Heartland był James Faigrieve (Jean, 1995, s. 67).

${ }^{4}$ Koncepcje Mackindera są w Rosji bardzo popularne. Do jego tekstów nawiązują liczne prace na temat eurazjatyzmu (zob. Eberhardt, 2005). Uzasadniają one, że opanowanie przez Cesarstwo Rosyjskie, a następnie Związek Sowiecki dużej części kontynentu eurazjatyckiego było nieuniknioną koniecznością dziejową. Ujawniony proces historyczny rozwijał się zgodnie z uniwersalnymi założeniami sformułowanymi przez Mackindera. Imperialna polityka Rosji znalazła w nim swego ideologicznego patrona.
} 
rakterze imperialistycznym, sprzeczne z doktryną marksistowską, o niewielkiej wartości naukowej. Były więc całkowicie ignorowane. W ostatnich latach zaczyna się do nich bardziej nawiązywać, ale jego dorobek geograficzny stał się obiektem analiz raczej ze strony politologów niż profesjonalnych geografów ${ }^{5}$. Można tu wspomnieć, że ostatnio ukazały się cenne omówienia twórczości Mackindera (Klin, 2008; Domke, 2009) oraz tłumaczenie jednego z jego ważniejszych tekstów, przygotowane przez R. Potockiego z odpowiednim komentarzem naukowym (Mackinder, 2009a). Dzięki tym pracom istnieje szansa, że opinie polskich geografów będą konstruowane na podstawie bardziej źródłowych ocen, a nie powierzchownych stereotypów. To jednak dopiero wstęp do poznania dorobku naukowego Mackindera i wpływu jego koncepcji na rozwój światowej geopolityki.

\section{Życie Mackindera i jego działalność organizacyjna i polityczna}

Halford John Mackinder urodził się 15 lutego 1861 r. w miejscowości Gainsborough położonej nad rzeką Trent, między miastami Sheffield a Lincoln

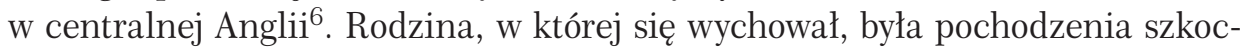
kiego, o czym zresztą świadczy brzmienie nazwiska. Jego ojciec, Draper Mackinder, był lekarzem, człowiekiem wykształconym, o wszechstronnych zainteresowaniach - także geograficznych. Młody Mackinder w 1868 r. rozpoczął naukę w gimnazjum im. Królowej Elżbiety, a następnie uczył się w Epsom College. W wieku 19 lat wstąpił do Christ Church na Uniwersytecie Oxfordzkim, gdzie studiował początkowo na kierunku przyrodniczym, a następnie wybrał specjalizację w zakresie geografii fizycznej, historycznej i politycznej. Po ukończeniu studiów rozpoczyna aktywną działalność organizacyjną i naukową. W 1889 r. wstępuje do Oxford Union Society i szybko zostaje jego prezesem. Równocześnie dokooptowano go do Królewskiego Towarzystwa Geograficznego. Jego osiągnięcia naukowe i dydaktyczne doceniono i w 1892 r. powołano na stanowisko dyrektora University Extension College. Zostaje współzałożycielem nowej wyższej uczelni London School of Economics.

Uzyskanie rangi uniwersyteckiego profesora otwiera mu możliwość kontaktów zagranicznych. W 1897 r. odwiedza ośrodki geograficzne w zachodniej Europie. Spotyka się z niemieckim geografem Josephem Partschem, twórcą

\footnotetext{
${ }^{5} \mathrm{~W}$ podręcznikach z zakresu geografii politycznej wydawanych w Polsce w ostatnich latach rola Mackindera jako wielkiego wizjonera geopolitycznego jest już odnotowana. Autorzy opracowań w różnym stopniu doceniają jego znaczenie w rozwoju myśli geopolitycznej - świadczy o tym nawet objętość poświęconego mu tekstu: na przykład w książce Z. Rykla (2006) są to dwa akapity, w opracowaniu S. Otoka (2003) pół strony. Więcej informacji zawiera monumentalne dzieło L. Moczulskiego (1999), gdzie osiągnięć Mackindera dotyczy 6 stron tekstu.

${ }^{6}$ Informacje o życiu Mackindera są zawarte w pracach B. Bloueta (1976, 1987, 2004), G. Kearnsa (1985) i G.R. Sloana (1999). W polskiej literaturze przedmiotu jego dokładny życiorys zamieszczono w opracowaniu R. Domke (2009) oraz w odrębnej broszurze zawierającej strzeszczenie oryginalnego tekstu Mackindera o „osi historii”, opracowane przez R. Potockiego (Mackinder, 2009a).
} 
koncepcji Mitteleuropy, następnie Ferdinando von Richthofenem, Eliséé Réclusem i innymi. Po powrocie do Oxfordu obejmuje kierownictwo Katedry Geografii, która koncentruje swoje badania na geografii politycznej świata.

Zainteresowania geograficzne i krajoznawcze kierują Mackindera do Afryki, gdzie w 1899 r. wchodzi na szczyt Mt. Kenya i odwiedza obszary położone w strefie równikowej. Po powrocie do Anglii jest już znanym i cenionym uczonym o znaczącym dorobku naukowym. Prowadzone przez niego wykłady akademickie ujawniają dużą erudycję faktograficzną. Dzięki nim uzyskuje propozycję pełnienia funkcji dyrektora w London School of Economics. To zaszczytne stanowisko zajmuje w latach 1903-1908. Prowadzi aktywną działalność publikacyjną. Wychodzą drukiem coraz to nowe jego książki i artykuły, które uzyskują rozgłos i uznanie. W czasie I wojny światowej oraz bezpośrednio po wojnie wyko-

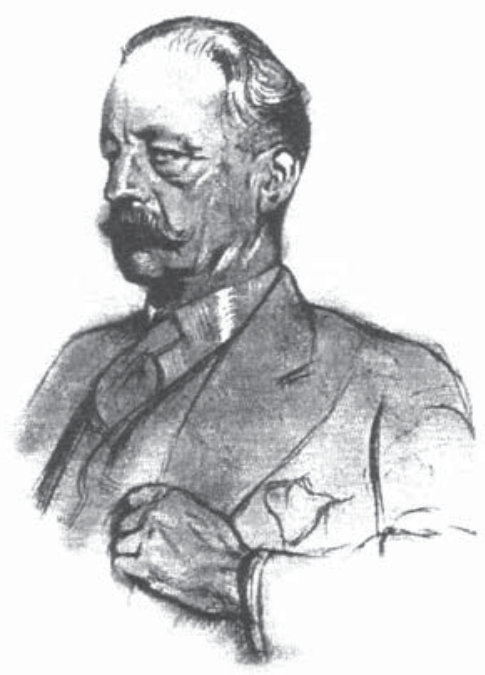
rzystywany jest przez władze brytyjskie przy realizacji poufnych działań o charakterze politycznym. Jedną z najtrudniejszych była jego misja do Rosji, do generała Antona Denikina walczącego w 1919 r. $\mathrm{z}$ armią czerwoną na froncie południowym. Pełnił tam funkcję brytyjskiego wysokiego komisarza przy armii białogwardyjskiej. W celu skoordynowania działań armii polskiej i armii Denikina zostaje wysłany przez tego rosyjskiego generała do Paryża i Warszawy. ${ }^{7}$ Najpierw spotyka się w Paryżu z Romanem Dmowskim, a następnie w Warszawie z Ignacym Paderewskim i Józefem Piłsudskim. Obecnie znając nastawienie Piłsudskiego do krucjaty antybolszewickiej w Rosji wiemy, że misja ta musiała zakończyć się niepowodzeniem. Władze polskie, a zwłaszcza Piłsudski, obawiały się zwycięstwa białych generałów, w tym głównie Denikina i nie nastąpiło współdziałanie militarne sił antybol-

\footnotetext{
${ }^{7}$ Misję Mackindera opisuje polski historyk następująco: „Przybył do Warszawy znakomity geopolityk brytyjski Sir Halford John Mackinder, «wysoki komisarz» brytyjski na Rosję południową, uważał on za główne swoje zadanie doprowadzenie do porozumienia między Polską Piłsudskiego a Rosją Denikina; po paryskim spotkaniu z Dmowskim - Mackinder odbył w Warszawie dwie długie rozmowy z Paderewskim i został przyjęty przez Piłsudskiego w Belwederze wraz z towarzyszącym mu posłem Rumboldem i gen. Keyesem, przebywającym stale przy Denikinie. Naczelnik państwa w rozmowie tej stwierdził, że nie zamierza prowadzić rokowań z bolszewikami (...). Generał Piłsudski powiedział mi - pisał Mackinder - że jako wojskowy sądzi iż mógłby w maju dokonać marszu na Moskwę, jako polityk jednak dodał: Co będę tam robił, gdy tam dotrę". Mackinder w odpowiedzi dał wyraz swemu przekonaniu, że na Moskwę maszerować można tylko „w sojuszu z Rosjanami” białymi oczywiście... Z Warszawy salonką Naczelnika Państwa udał się Mackinder do kwatery Denikina. Rozmowa z gen. Wranglem (...) pogłębiła w nim przekonanie, że Denikin o własnych siłach pokonać bolszewików nie zdoła... Mackinder w rozmowach z Denikinem, stwierdzając słabość jego sił w stosunku do ogromu zadania, doradził mu kategorycznie szukać sojuszników przede wszystkim w Polsce, dodatkowo zaś w Finlandii, Estonii, Łotwie, Gruzji, Azerbejdżanie i Rumunii (Pobóg-Malinowski, 1967, s. 400-401).
} 
szewickich. Mało tego, została celowo zatrzymana ofensywa wojsk polskich, aby ułatwić armii bolszewickiej pokonanie Denikina ${ }^{8}$.

Po zakończeniu swoich misji Mackinder powraca do Wielkiej Brytanii. Zostaje mianowany na stanowisko kierownika Katedry Geografii na Uniwersytecie Londyńskim, a jednocześnie pełni liczne funkcje honorowe w stowarzyszeniach geograficznych i kolonialnych. Za swą działalność naukową i polityczną uzyskuje od króla brytyjskiego Jerzego V tytuł szlachecki. W okresie międzywojennym ogranicza działalność akademicką i naukową z powodu pogarszającego się stanu zdrowia. Pomimo to jego rola jako wybitnego uczonego i autora oryginalnych, wyjątkowo inspirujących koncepcji i idei geopolitycznych jest na świecie coraz bardziej doceniana. Już za życia staje się niekwestionowanym klasykiem, którego dzieła tłumaczone są na wiele języków i komentowane przez geografów i politologów. Umiera 6 marca 1947 r. w wieku 86 lat.

\section{Osiągnięcia naukowe Mackindera}

Pierwszą znaną pozycją naukową Mackindera jest opublikowana w $1887 \mathrm{r}$. rozprawa pt. On the scope and methods of geography. Zajął się w niej założeniami teoretycznymi i metodologia geografii. Postulował, aby geografia nie była nauką opisową -powinna mieć przede wszystkim walory objaśniające i tłumaczyć zjawiska zachodzące na świecie, maksymalnie wykorzystując dorobek nauk historycznych. Na podstawie dorobku obu tych dziedzin można zrozumieć genezę, a następnie konsekwencje procesów politycznych, które mają zawsze wymiar czasowo-przestrzenny. Stał na stanowisku, że „podstawą nauk geograficznych jest zawsze przestrzeń fizyczna, która w swoich rozważaniach przyczynowo-skutkowych powinna uwzględniać zarówno czynniki środowiskowe, jak i działalność człowieka w perspektywie długiego trwania” (Mackinder, 2009a, s. 5). Twierdził, że „geografia jest samodzielną dyscypliną z własną metodologią”. Zdefiniował ją jako „naukę o rozmieszczeniu”, uwzględniającą dorobek tradycyjnej biologii, „w której siły są ze sobą powiązane i współgrają względem siebie nawzajem”. Nie darmo Mackinder uznawany jest za „ojca geografii brytyjskiej" (Domke, 2009, s. 34-35).

Kolejną pozycją, która zdobyła rozgłos, była wydana w 1902 r. Britan and the British Seas - typowe studium geograficzne, obejmujące całokształt problemów z zakresu geografii fizycznej i ekonomicznej. Uwypuklił w nim przyrodnicze czynniki sprawcze oraz ich konsekwencje determinujące działalność człowieka w przestrzeni. Podkreślał znaczenie morza jako czynnika nie tylko rozdzielającego, lecz również integrującego i spajającego obszary lądowe. Na ówczesne

${ }^{8}$ Było to wynikiem poufnego porozumienia zawartego między stroną polską a bolszewikami w dniu 3 XI 1919 r., które miało uniemożliwić zwycięstwo Denikina. N. Davies (1997, s. 70) podaje następującą informację o tym układzie: „Zgodnie z instrukcjami Boerner poinformował Marchlewskiego, że okazywanie pomocy Denikinowi nie leży w interesie Polski i że zrezygnowano z ataku na Mozyrz, który w połączeniu z natarciem Denikina na Orzeł mógł raz na zawsze złamać sowiecki front południowy”. 
czasy było to dzieło nowatorskie, głównie z powodu wskazania roli powiązań i współzależności w wymiarze czasu i przestrzeni.

Podane dwie pozycje miały charakter podręcznikowy i były jedynie punktem wyjścia do ujęć koncepcjonalnych, które przyniosły mu uznanie i sławę. Opracowaniem wyjątkowym, o przełomowym znaczeniu, było dzieło o tzw. „geograficznej osi historii” (Mackinder, 1904). Zawarł w nim wstępną koncepcję roli Heartlandu w dziejach świata, później doskonaloną, weryfikowaną i uszczegółowianą (Mackinder, 1919, 1943).

Mniej znanym, ale ważnym tekstem geopolitycznym w dorobku Mackindera jest wydany w 1924 r. The Nations of the Modern World. Zawarta w niej wizja okazała się dość prorocza, spełniła się bowiem w dużym stopniu po II wojnie światowej. Autor zakładał, że w przyszłości ukształtuje się „cywilizacja północnego Atlantyku", łącząca Europę z Ameryką Północną. Miała się ona rozpościerać od Gór Skalistych na zachodzie po Wołgę na wschodzie. W rzeczywistości jej wschodnią granicą okazała się Łaba. Wynikało to z trudnego do przewidzenia faktu, że obszar podporządkowany Związkowi Sowieckiemu, dzięki zwycięstwu Stalina, zwiększył się o wszystkie kraje położone między Bałtykiem, Morzem Czarnym i Adriatykiem.

Pozostałe opracowania Mackindera miały już mniejsze znaczenie poznawcze. Ze względu na wątek polski warto jedynie wspomnieć o relacji, którą opublikował po wspomnianej juz misji politycznej w sztabie gen. Denikina (Blouet, 1976, s. 228-236) oraz po przeprowadzonych rozmowach z najwybitniejszymi politykami polskimi. Dzięki tym osobistym kontaktom oraz poznaniu z autopsji obszarów środkowo-wschodniej Europy wyrobił sobie samodzielną opinię o sytuacji polityczno-militarnej Polski oraz jej trudnych dylematach geopolitycznych. Odnosił się do niej przyjaźnie i tym odróżniał się od wielu ówczesnych polityków brytyjskich. Zdawał sobie doskonale sprawę z niekorzystnej konfiguracji polskich granic, zwłaszcza granicy polsko-niemieckiej. Uzasadniał, że odrodzone państwo polskie jest zagrożone zarówno od wschodu, jak i od zachodu. Potencjalnie grozi to jego unicestwieniem i odtworzeniem wspólnej granicy niemiecko-rosyjskiej. Aby do tego nie dopuścić, wysuwał określone propozycje, które wzmocniłyby położenie geopolityczne Polski. Proponował między innymi likwidację Prus Wschodnich i włączenie ich w całości do Polski (wiązałoby się to z wysiedleniem ludności niemieckiej), Polska z kolei miała zrezygnować z zachodniej Wielkopolski. Miało to zredukować długość granicy między obu państwami. Były to sugestie już wówczas całkowicie nierealne, świadczą jednak o wizjonerstwie i zamiłowaniu do konstruowania odważnych projektów geopolitycznych.

Tworzone w tym czasie koncepcje nie były ograniczone tylko do kwestii polskiej. W styczniu $1920 \mathrm{r}$. Mackinder wystosował bowiem memorandum do premiera brytyjskiego Lloyda George'a, w którym postulował budowę bloku politycznego na obszarze tzw. Międzymorza złożonego z Polski, Ukrainy, Białorusi 
i południowej Rosji. W takiej sytuacji bolszewicka Rosja miała być daleko przesunięta na północ i wschód. Zwycięstwo bolszewików zniweczyło te trudne do urzeczywistnienia projekty, podobnie uległy dezaktualizacji jego apele wzywające do obrony suwerenności krajów kaukaskich.

Ogólnie można ocenić dorobek publikacyjny Mackindera jako wielowątkowy, gdyż dotyczył problematyki historycznej, przyrodniczej, politycznej, ekonomicznej i geograficznej (Mackinder, 1919). Świadczy o szerokich zainteresowaniach, wiedzy i inwencji twórczej. Pomimo to byłby przypuszczalnie zapomniany, gdyby nie dzieła poświęcone Heartlandowi, które zyskały światowy rozgłos. One przyniosły autorowi prestiż i międzynarodową sławę.

\section{Koncepcja Heartlandu Mackindera}

Wstępną hipotezę koncepcji kontynentalnej sformułował Mackinder w $1904 \mathrm{r}$. $\mathrm{w}$ tekście pt. The geographical pivot of history ${ }^{9}$. Została ona później rozszerzona i pełny wymiar ideowo-koncepcjonalny uzyskała w opracowaniu Democratic Ideals and Reality (1919). Późniejsze uzupełnienia dokonane przez autora były już nieznaczne i nie zmieniły strony koncepcjonalnej. $\mathrm{O}$ ile $\mathrm{w}$ pierwszej ze swych książek Mackinder nie używa jeszcze pojęcia Heartlandu i mówi o obszarze osiowym (rdzeniowym), o tyle $\mathrm{w}$ drugiej i trzeciej termin Heartland jest już konsekwentnie wykorzystywany i stosowany. Kwestie czysto terminologiczne nie mają istotnego znaczenia dla istoty i sensu samej koncepcji. Zarówno tzw. obszar osiowy, jak i Heartland odnoszą się do północnowschodniej części kontynentu eurazjatyckiego, graniczącego z Arktyką. Mieści ona prawie cała Syberię, z wyjątkiem obszaru przypacyficznego. Na południu w obrębie Heartlandu znajdują się obszary północnego Pakistanu i Afganistanu, na zachodzie zaś zasięg wydzielonego terytorium przekracza Ural i dochodzi do Wołgi (ryc. 1).

W stosunku do pierwotnej koncepcji Mackinder dokonał w 1919 r. pewnych weryfikacji o charakterze geograficznym, redukując Heartland o bezludne obszary północno-wschodniej Syberii. Wersja koncepcji powstała po I wojnie światowej jest traktowana przez późniejszych badaczy jako najważniejsza i stanowi podstawę wszelkich ocen merytorycznych. Nie znaczy to, że po 1919 r. Mackinder swej koncepcji nie zmieniał - wprost przeciwnie: stale próbował ją udoskonalić. Z dużą uwagą obserwował on wydarzenia polityczne na świecie. Zazwyczaj nie były one dla niego zaskakujące. Ewolucja ich była zwykle zgodna

\footnotetext{
${ }^{9}$ Pojęcie pivot jest różnie tłumaczone na język polski, zazwyczaj jako „oś” (Baczwarow i Suliborski, 2003, s. 83; Domke, 2009, s. 38; Sykulski, 2009, s. 74) lub „sworzeń” (Jean, 2003, s. 67; Brzeziński, 1999, s. 49). Z kolei L. Moczulski (1999, s. 14) uważa, że oba tłumaczenia mają pełne prawo obywatelstwa. We wspomnianej pracy C. Jeana w przypisie tłumacza wyjaśniono, że termin „sworzeń” w tłumaczonych książkach Z. Brzezińskiego wykorzystano ze względu na fakt, że pojęcie „oś” kojarzy się z innymi koncepcjami geopolitycznymi. Polskie tłumaczenie książki Mackindera ukazało się pod tytułem Geograficzna oś historii (Mackinder, 2009a, s. 14). Sądzę, że to definitywnie zakończyło ten spór onomastyczny.
} 
z tym, co zarysował w swojej uniwersalnej koncepcji. Między innymi przewidywał, że państwo tworzące Heartland, czyli Związek Sowiecki ${ }^{10}$, pokona swoich przeciwników i rozpocznie ekspansję militarną i polityczną na obszary peryferyjne. Z czasem stanie się konkurentem wobec mocarstw morskich, które nie są w stanie wyeliminować jego pozycji hegemonistycznej na świecie.

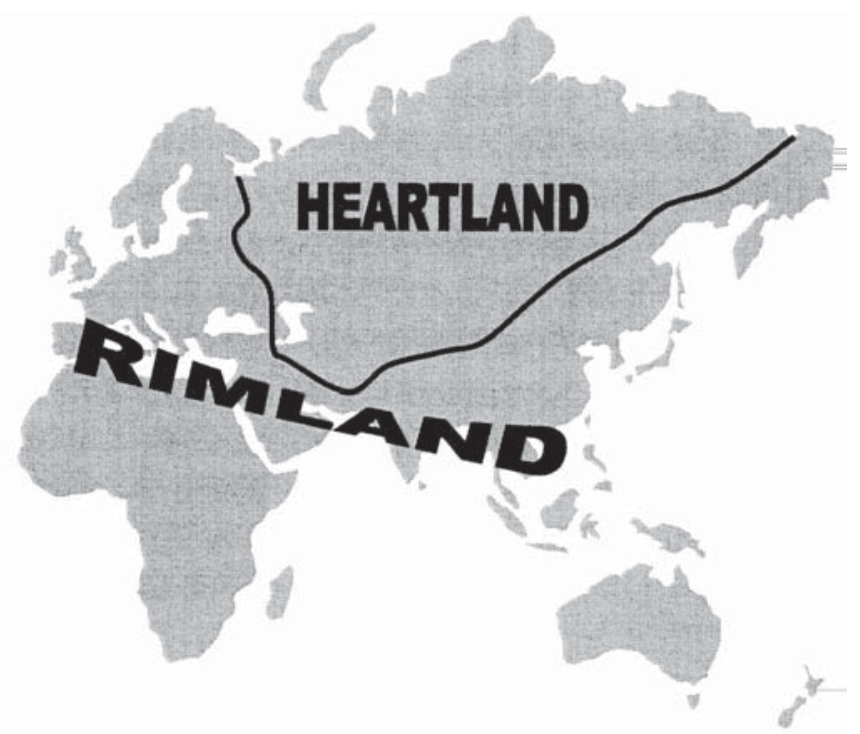

Ryc. 1. Heartland i Rimland

Heartland and Rimland

Źródło/Source: L. Sykulski (2011, s./p. 15).

Dlatego w 1943 r., gdy już było pewne, że jego przewidywania spełniają się i ZSRR wyjdzie z wojny potężniejszy, a jego armie wychodzące z wnętrza Heartlandu zaczęły przesuwać się na zachód, Mackinder postanowił po raz trzeci powrócić do swojej idei. Zbliżając się do 82 roku życia wydał artykuł pt. The round world and the winning of the peace, zawierający dalszy tok rozważań nad Heartlandem. Pewne kwestie ponownie weryfikuje. Przede wszystkim wielkość Heartlandu ulega zmniejszeniu, a z jego terytorium wydziela się tzw. Lenaland (Kraj rzeki Leny). Ponadto Mackinder koncentruje uwagę na obszarze między Bałtykiem a Adriatykiem - można przypuszczać, że zdawał sobie doskonale sprawę z zamierzeń polityki sowieckiej.

Oceniając wszystkie modyfikacje jakie przeprowadził Mackinder między 1904 a 1943 r. należy wyraźnie stwierdzić, że nie zmieniły one istoty koncepcji, a nawet utwierdziły autora w słuszności założeń i poglądów dotyczących roli

\footnotetext{
${ }^{10}$ Autor konsekwentnie używa pojęcia „Związek Sowiecki”, zaś w skrótowej formie ZSRR. Wyjaśnienie m.in. w: P.Eberhardt (2010, s. 23).
} 
Heartlandu w dziejach politycznych świata. Zmiany o charakterze delimitacyjnym miały w gruncie rzeczy znaczenie drugorzędne i nie one świadczyły o wartości zaprezentowanej koncepcji.

W pierwszej ze swych książek poświęconych „geograficznej osi historii” Mackinder zwrócił szczególną uwagę na rolę północno-wschodniej części kontynentu eurazjatyckiego jako regionu, z którego przez wiele wieków wychodziły najazdy ludów nomadycznych. Miały one do wyboru dwie drogi ekspansji zewnętrznej. Pierwszą był step pontyjski między Uralem a Morzem Kaspijskim, drugą usytuowany bardziej na południe szlak anatolijsko-bałkański. Poprzez te bramy koczownicy docierali do Europy i Azji Mniejszej.

Nowy okres historii rozpoczął się od wypraw Kolumba, kiedy to narody zachodnioeuropejskie poprzez morza tworzyły nowe imperia kolonialne. Świat morski nie był ograniczony barierami naturalnymi, lecz jedynie przestrzenią, którą można było pokonać. W tym samym czasie Rosjanie zaczęli stopniowo przesuwać się na wschód. Dotarli do Pacyfiku i całkowicie opanowali północno-wschodnią część kontynentu eurazjatyckiego. Te dwa procesy przyniosły istotne konsekwencje polityczne. Powstały dwie potęgi: jedna związana z lądem, druga zaś z morzem. Są one skazane na rywalizację. Mackinder przewiduje, że ta pierwsza w rywalizacji o prymat nad światem uzyska przewagę. Wyjaśnia to następująco: „Dominacja lądu nad morzem pozostaje (jednak) nadal (faktem), a niedawne wydarzenia potwierdziły tę supremację. Kiedy tallasokratyczne narody Europy Zachodniej przekroczyły ocean, odkrywały (inne) kontynenty oraz określały morskie granice Azji, Rosja organizowała Kozaków i emigrantów z północnych kresów, utrzymywała porządek na stepie, doprowadzając do zderzenia jej osadnictwa z koczownikami talerskimi. Epoka Tudorów (w Anglii) doprowadziła do rozwoju morskiej ekspansji Europejczyków oraz do stworzenia potęgi Moskwy wynikającej z władania (przez nią) Syberią. Ekspansja osadnictwa (rosyjskiego) ku Wschodowi była wydarzeniem o ogromnym znaczeniu, odsuwając w tym samym czasie na bok zderzenie tych dwóch (wspomnianych) żywiołów: (lądu i morza). To prawdopodobnie jeden z najbardziej zdumiewających zbiegów okoliczności w historii, że morska i lądowa ekspansja Europy kontynuuje, w pewnym sensie, starożytną opozycję między (talassokratycznie nastawionymi) Grekami a (tellurokratycznymi) Rzymianami" (Mackinder, 2009a, s. 41-42).

W dalszych rozważaniach Mackinder charakteryzuje ekspansję „morza” czyli narodów zachodnich oraz „lądu”, który znalazł się pod dominacją Rosji. Umożliwia mu to sformułowanie ostatecznych wniosków, a mianowicie: „Podsumowując ten pobieżny przegląd dziejowy nie sposób nie zauważyć, że istnieje (zatem) określona korelacja między historią a geografią. Czyż pewna stałość związków przyczynowo-skutkowych nie staje się wówczas oczywista? Czyż regionem rdzeniowym Wielkiej Polityki nie jest ogromny obszar Eurazji, niedostępny dla statków, lecz u zarania starożytności szeroko otwarty dla konnych nomadów, a dziś mający zostać pokryty siecią linii kolejowych? Tutaj były 
i są warunki do militarnej i ekonomicznej mobilności, bardziej dalekosiężnej i o specyficznym charakterze. Rosja jest (bowiem) następcą imperium mongolskiego. Jej nacisk na Finlandię, Skandynawię, Polskę, Turcję, Persję, Indie i Chiny zastępuje (niegdysiejsze) odśrodkowe ataki ludów stepowych. Z perspektywy globalnej zajmuje ona centralną pozycję strategiczną (podobną do tej), jaką mają Niemcy w Europie. Może atakować i być atakowana ze wszystkich stron z wyjątkiem północy" (Mackinder, 2009a, s. 45; ryc. 2).

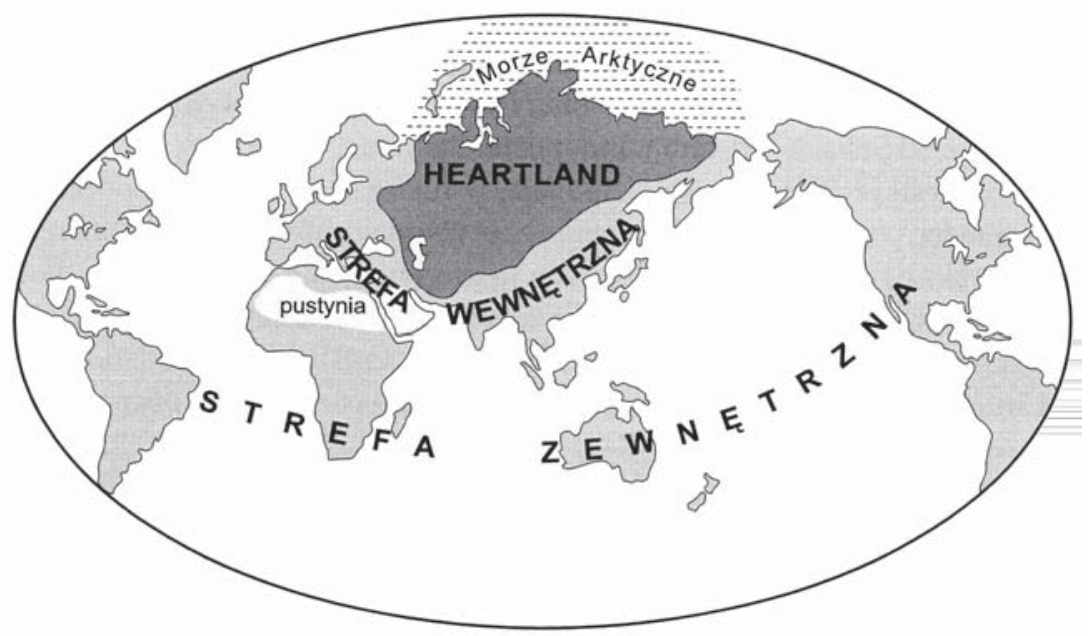

Ryc. 2. Geopolityczny model świata Mackindera

Mackinder's geopolitical model of world

Źródło/Source: L. Moczulski (1999, s./p. 13, za: Mackinder, 1981, s./p. 260).

W dalszym ciągu swych wywodów Mackinder dzieli świat na wielkie strefy. Obszarem odniesienia jest obszar rdzeniowy (czyli w przybliżeniu Rosja). Wokół niej ukształtowały się strefa wewnętrzna, czyli tzw. strefa półksiężyca wewnętrznego, w której znajdują się Niemcy, Austria, Turcja, Indie i Chiny. Bardziej oddalona jest tzw. strefa zewnętrzna, do której zalicza Wielką Brytanię, południową Afrykę, Australię, Stany Zjednoczone, Kanadę i Japonię (Moczulski, 1999, s. 14).

W następnej pracy, opublikowanej w 1919 r., określa i definiuje bardziej precyzyjnie swoją uprzednią hipotezę badawczą ${ }^{11}$. Wprowadza już pojęcie Heartlandu na miejsce obszaru osiowego (rdzeniowego).

${ }^{11}$ Tezę tę formułuje następująco: „Rzeczywisty stosunek sił politycznych w danym czasie jest wytworem warunków geograficznych, ekonomicznych jak i strategicznych oraz względnej liczebności, dzielności, wyposażenia i organizacji rywalizujących narodów. Wielkości geograficzne są w kalkulacjach bardziej mierzalne i bardziej stale niż ludzkie. Dlatego ta formuła może być zastosowana zarówno do minionej historii jak i bieżącej polityki" (Mackinder, 1919, s. 263; Moczulski, 1999, s. 12). 
Biorąc pod uwagę zachodzące przez stulecia procesy historyczne oraz przede wszystkim uwarunkowania geograficzne Mackinder tworzy geopolityczny model świata. Wydziela „Światową Wyspę” (World Island) składającą się z Heartlandu oraz strefy wewnętrznej (tzw. Inner of Marginal Crescent). „Światowa Wyspa” zawiera główną część kontynentalną lądu wszechświatowego. Zamieszkuje na niej zdecydowana większość ludności świata. Tu działy się najważniejsze wydarzenia historyczne i ona decyduje o przyszłości świata. Obejmuje połączony kontynent Europy, Azji i Afryki. Jej rdzeniem i najważniejszą częścią jest Heartland, zaś do strefy zewnętrznej zalicza zachodnią i centralną Europę, basen Morza Śródziemnego, Bliski Wschód, Indie, Indochiny i Chiny oraz północną Afrykę. „Światową Wyspę” otacza „Wszechświatowy Ocean”, na którym rozrzucone są pojedyncze wyspy, tzn. Północna i Południowa Ameryka, Australia, wyspy Oceanu Indyjskiego i Pacyfiku (np. Japonia) ${ }^{12}$. Zalicza je do tzw. zewnętrznej strefy półksiężyca. Interesujące, że Wielkiej Brytanii nie włącza do „Światowej Wyspy" lecz do Outer Crescent (Wszechświatowego Oceanu). Tę wyspiarską zewnętrzną część świata określa jako Outer or Insular Crescent. Mackinder przypomina, że siły militarne opuszczające Heartland i zmierzające do podbojów wielokrotnie próbowały opanować strefę położoną na pobrzeżu Pacyfiku, Oceanu Indyjskiego lub Atlantyku. Cykliczne ekspansje nie były jednak w stanie w całości i na dłużej zdominować tej strefy przylegającej do otwartych oceanów. Utworzenie podporządkowanej politycznie „Światowej Wyspy” przekraczało do tej pory możliwości Heartlandu. W przyszłości nie można tego wykluczyć. Należy założyć, że pojawi się mocarstwo kontynentalne, które po opanowaniu Heartlandu podejmie próbę podporządkowania strefy wewnętrznej. W przypadku zrealizowania tego zamierzenia i dotarcia do światowego oceanu ekspansywne imperium lądowe uzyska globalną hegemonię nad wszystkimi kontynentami (Sykulski, 2009, s. 55).

Na podstawie tak sformułowanej hipotezy badawczej Mackinder redaguje swą słynną doktrynę, którą traktuje jako podstawowe i uniwersalne prawo geopolityczne. Brzmi ono następująco: „Kto panuje nad wschodnią Europą, ten włada 'Heartlandem', kto panuje nad 'Heartlandem', ten włada 'Światową Wyspą', kto panuje nad 'Światową Wyspą, ten włada światem”13.

Według Mackindera tak oczywista hipoteza nie wymaga uzasadnienia. Był przekonany, że jest to prawda absolutna potwierdzona przez historię i geografię. To dogmatyczne i deterministyczne podejście przewija się $\mathrm{w}$ jego rozumowaniu i ostatecznych konkluzjach. Mackinder formułuje wyraźnie zdefiniowaną

\footnotetext{
12 Problematykę tę omawia Mackinder we wspomnianej książce pt. Democratic Ideals and Reality (1919). Trzeci rozdział tego ważnego opracowania, odniesiony do rozwoju potęgi morskiej, został przetłumaczony na język polski (Mackinder, 2009b, s. 205-227), nie wymaga więc rozpatrzenia w tym miejscu.

${ }^{13} \mathrm{~W}$ angielskiej wersji oryginalnej brzmi ono: „Who rules the East Europe, commands the Heartland, who rules the Heartland, commands the World-Island, who rules the World-Island, controls the World".
} 
doktrynę geopolityczną, którą pomimo jej dowolności i subiektywności zaakceptowało wielu geografów, wysoko oceniając oryginalność i wyjątkowość. Została zaadoptowana i wykorzystana w konkretnej działalności politycznej, pomimo że jest w gruncie rzeczy koncepcją abstrakcyjną, wytworem genialnej wyobraźni, a nie racjonalnego uzasadnienia. Nic dziwnego, że stała się również obiektem ostrej krytyki ze strony środowisk naukowych. Nie zmienia to faktu, że Mackinder uzyskał miano jednego z najwybitniejszych geopolityków pierwszej połowy $\mathrm{XX}$ wieku.

Nie znaczy to, że Mackinder był zwolennikiem opanowania świata przez państwo, które zdominuje Heartland. Wprost przeciwnie - przestrzega, że nie jest to wariant optymalny. Państwa morskie poprzez rozsądną i celową politykę mogą ten scenariusz opóźnić lub nawet udaremnić. Jednym ze sposobów przeciwdziałania ekspansji imperium kontynentalnego, tak aby nie stanowiło zagrożenia dla mocarstw morskich, jest obrona terenów przylegających do oceanów, czyli pobrzeży i wód terytorialnych. Nie wolno w żadnym przypadku dopuścić, aby imperium pochodzące z Heartlandu przebiło się do otwartego oceanu. Myślał tu głównie o Oceanie Indyjskim, ale też o Atlantyku.

Przewidywał, że trzy państwa imperialne mogą ewentualnie dążyć do zdominowania Heartlandu, a następnie strefy zewnętrznej. Mogą to być Niemcy, które po pokonaniu Rosji będą zmierzać do hegemonii nad „Światową Wyspą”, ewentualnie Rosja. Ta możliwość była dla niego najbardziej prawdopodobna. Wymieniał również Chiny jako imperium, które w odległej perspektywie może zagrozić stabilności świata. Był sceptyczny wobec możliwości opanowania Chin przez Rosję, ze względu na różnice potencjału demograficznego. Żadne bowiem państwo nie jest w stanie okupować Chin. Obawiał się do pewnego czasu (tj. do 1941 r.) sojuszu niemiecko-rosyjskiego. Przestrzegał przed możliwością powstania potężnych Niemiec lub Rosji. Niepokoił go zwłaszcza wzrost siły militarnej i aspiracje polityczne Rosji. Mackinder zastanawiał się nad sposobami niedopuszczenia do groźnego w skutkach scenariusza. Proponował między innymi wzmocnienie państw położonych między Rosją a Niemcami (Middle Trier). Pojedynczo są one słabe, powinny zatem utworzyć federację obronną i uzyskać wsparcie od mocarstw morskich. Od tego może zależeć utrzymanie niezależności tego obszaru i pokoju w Europie. Zdawał sobie sprawę z ich dezintegracji i dlatego przewidywał, że ich zniewolenie przez Rosję staje się coraz bardziej prawdopodobne. Stanowi to jeden z wyjściowych warunków opanowania przez Rosję całego Heartlandu, a następnie „Wyspy Światowej”. Przewidywania Mackindera po jego śmierci zaczęły się częściowo urzeczywistniać. Związek Sowiecki w pełni opanował Heartland i następnie zaczął zmierzać do zajęcia „Wyspy Światowej”. Wojny w Wietnamie czy Afganistanie oraz wsparcie państw arabskich wskazywały jednoznacznie na plany Kremla. Zgodnie z założeniami teoretycznymi Mackindera świat stał się dwubiegunowy. Między mocarstwem 
kontynentalnym (ZSRR) a mocarstwami morskimi rozpoczęły się zmagania o prymat $\mathrm{w}$ świecie.

W ostatniej ze swoich prac (z 1943 r.) uwzględnił on w większym zakresie kwestie geostrategiczne oraz rozwój techniczny w prowadzeniu wojen. Doceniał zwłaszcza rozwój lotnictwa. Wcześniej kolej ułatwiała przemieszczanie sił wewnątrz mocarstwa kontynentalnego dając mu przewagę nad siłami morskimi, zmuszonymi do operowania na liniach zewnętrznych. We współczesnej wojnie lotnictwo uzyskało zdolność uderzenia na przyczółki usytuowane na peryferiach, bez obawy o zniszczenie baz lotniczych przez mocarstwa morskie. Podstawowe znaczenie Mackinder przyznawał zaś „środkowemu oceanowi” (Midland Ocean), tzn. Północnemu Atlantykowi, czyli strefie położonej między Stanami Zjednoczonymi, Wielką Brytanią i kontynentem europejskim (Jean, 2003, s. 70).

Mackindera interesowały nie tylko kwestie globalne. Nie pomijał problematyki regionalnej, zwłaszcza takiej, która dotyczyła konfrontacji między lądem a morzem. Między innymi dokonał podziału Europy na część zachodnią i wschodnią. Pierwsza z nich miała charakter wyspowy lub półwyspowy, druga bardziej lądowy, a granica przebiegała od Morza Północnego do Adriatyku, dzieląc Niemcy; Berlin i Wiedeń były po stronie wschodniej. Przewidział więc w przybliżeniu późniejszy podział Niemiec na strefy okupacyjne (Klin, 2008, s. 199-200). Równocześnie postulował, aby Europa Wschodnia składała się z trzech części: wschodnich Niemiec, Rosji oraz państw położonych między nimi. Wymienił tu siedem narodów: Polaków, Czechów i Słowaków (The Bohemians), Węgrów, Słowian południowych (Serbów, Chorwatów i Słoweńców), Rumunów, Bułgarów oraz Greków. Szczególne znaczenie miała Polska jako niepodległe silne państwo położone między Rosją a Niemcami (Klin, 2008, s. 200).

\section{Uwagi końcowe}

Doktryna Heartlandu zaproponowana przez Mackindera jest jedną z najbardziej znanych wizji geopolitycznych. Twórca przyjął założenie, że świat jest skazany na konfrontację polityczną i militarną między imperium kontynentalnym, które musi być usytuowane w północno-wschodniej części Eurazji, a mocarstwami panującymi na morzach. Imperium lądowe po opanowaniu w pełni Heartlan$d u$, tej kontynentalnej twierdzy niedostępnej dla potęg morskich, uzyskuje możliwość ekspansji w kierunku tzw. strefy wewnętrznej, czyli wybrzeży oceanu. W przypadku pomyślnej realizacji tego przedsięwzięcia ma szanse zdominowania tzw. „Światowej Wyspy”, czyli całego kontynentu eurazjatyckiego. Konsekwencją byłoby opanowanie całego świata.

Minęło już ponad 60 lat od śmierci twórcy tej deterministycznej, ale i oryginalnej hipotezy badawczej. Możemy więc ocenić, czy zarysowana wizja Mackindera urzeczywistniła się w praktyce, czy też była abstrakcyjną mrzonką daleką od realiów świata drugiej połowy XX wieku. 
Przez kilkadziesiąt lat wydawało się, że teoretyczny scenariusz opracowany przez Mackindera w sposób genialny oddaje faktyczną ewolucję polityczną świata. Świadczyło o tym wiele zdarzeń zachodzących na arenie międzynarodowej. Stopniowo wzrastała potęga Związku Sowieckiego, mocarstwa kontynentalnego panującego nad Heartlandem. Jedno z mocarstw morskich, Wielka Brytania, stała się drugorzędnym państwem. Kolejne mocarstwo morskie, Japonia, zostało pokonane i upokorzone. Jedynym konkurentem pozostały Stany Zjednoczone panujące nad „Wszechświatowym Oceanem”. Stanowiły ostatnią redutę broniącą państwa morskie przed ekspansją Heartlandu, zmierzającą do politycznego i ideologicznego opanowania świata. Przez kilkadziesiąt lat (1945-1989) trwała nieubłagana konfrontacja i obrona „Wielkiej Wyspy”. Zmagania te zakończyły się klęską mocarstwa kontynentalnego i zwycięstwem potęgi morskiej, którą reprezentowały Stany Zjednoczone. Przez kilka dziesięcioleci świat był dwubiegunowy. Po jednej stronie barykady stał „ląd” - Heartland, po drugiej „morze”. Ewolucja procesów politycznych zachodziła zgodnie z przewidywaniami Mackindera, a jego wizja okazała się prorocza. Dalsze wydarzenia polityczne nie przebiegały już jednak według teoretycznych założeń Mackindera ${ }^{14}$. Rywalizacja przyniosła klęskę mocarstwu kontynentalnemu. Świat dwubiegunowy przekształca się stopniowo po 1989 r. w układ policentryczny. Na kontynencie eurazjatyckim kształtują się cztery ośrodki siły, tzn. Chiny, Indie, Rosja oraz Unia Europejska. Przypuszczalnie największą rolę odgrywać będą położone na pograniczu Heartlandu Chiny, które mają ambicje być mocarstwem nie tylko kontynentalnym, lecz i morskim. Te cztery potęgi są na tyle silne i oddalone od siebie, że nie istnieje możliwość detronizacji żadnej z tych potęg i zdominowania przez jedno z nich kontynentu eurazjatyckiego. Posiadanie przez Rosję ograniczonego terytorialnie Heartlandu ma już tylko znaczenie symboliczne. Potęga Heartlandu, o którym tak wiele pisał Mackinder, ulega więc marginalizacji, będąc jedynie wspomnieniem niedawnej przeszłości. Koncepcja siłą rzeczy zatraca swą użyteczność praktyczną oraz walory wyjaśniające ${ }^{15}$, powoli się dezaktualizując. Nie umniejsza to wielkości twórcy koncepcji kontynentalnej. Mackinder był bez wątpienia jednym z wielkich wizjonerów klasycznej geopolityki, który usiłował określić w spójnej koncepcji prawa rządzące rozwojem politycznym świata.

14 Można sobie zadać pytanie, czy po II wojnie światowej istniała realna możliwość (głównie w latach 1950. i 1960.) zwycięstwa Heartlandu, czy też jego spektakularna klęska była nieunikniona. Rozważania na temat tzw. alternatywnej historii są niezbyt sensowne, niemniej warto przypomnieć, że przez kilka dziesięcioleci przewaga militarna imperium sowieckiego była zdecydowana. Nie miało ono równoważnego przeciwnika na kontynencie eurazjatyckim. Dysponowanie przez mocarstwo morskie (USA) bronią atomową stanowiło jedyną obronę wybrzeży Atlantyku czy Oceanu Indyjskiego. Obawa przed katastrofą nuklearną uratowała świat przed III wojną światową. Tego zaś Mackinder nie mógł przewidzieć.

15 Nie znaczy to, że wraz z końcem XX wieku wizje Mackindera całkowicie zatraciły swą przydatność poznawczą. Świadczą o tym prace, w których omówione koncepcje geopolityczne są adoptowane do wyjaśniania współczesnych zjawisk politycznych (np. Karolczak, 2009). 


\section{Piśmiennictwo}

Baczwarow M., Suliborski A., 2003, Kompendium wiedzy o geografii politycznej i geopolityce. Terminologia, Wydawnictwo Naukowe PWN, Warszawa.

Blacksell M., 2008, Geografia polityczna, Wydawnictwo Naukowe PWN, Warszawa.

Blouet B., 1976, Sir Halford Mackinder as British high commissioner to south Russia 1919-1920, Geographical Journal, 142, London, s. 228-236.

Blouet B., 1987, Halford Mackinder. A Biography, College Station, A.M. University Press, Texas.

-, 2004, The imperial vision of Halford Mackinder, Geographical Journal, 170, 4, London, s. 322-329.

Brzeziński Z., 1999, Wielka szachownica: główne cele polityki amerykańskiej, Świat Książki, Warszawa.

Davies N., 1997, Orzet biaty, czerwona gwiazda, Wydawnictwo Znak, Kraków.

Domke R., 2009, John Halford Mackinder (1861-1947): zarys biografii naukowej, Geopolityka, II, 2(3), Częstochowa, s. 33-41.

Eberhardt P., 2005, Rosyjski eurazjatyzm i jego konsekwencje geopolityczne, Przegląd Geograficzny, 77, 2, s. 171-191.

-, 2009, Koncepcje geopolityczne Karla Haushofera, Przegląd Geograficzny, 81, 4, s. 527-549.

-, 2010, Migracje polityczne na ziemiach polskich (1939-1950), Instytut Zachodni, Poznań.

Flint C., 2008, Wstęp do geopolityki, Wydawnictwo Naukowe PWN, Warszawa.

Jean C., 2003, Geopolityka, Ossolineum, Wrocław.

Karolczak K., 2009, Wspótczesny terroryzm w świetle teorii Halforda Mackindera, Geopolityka, II, 2(3), Częstochowa, s. 104-113.

Kearns G., 1985, Halford John Mackinder 1861-1947, Geographers: Biobibliographical Studies, 9, London, s. 71-86.

Klin T., 2008, Wizje ładu międzynarodowego w niemieckiej i anglosaskiej myśli geopolitycznej w okresie II wojny światowej, Wyd. A. Marszałek, Toruń.

Mackinder H.J., 1887, On the scope and methods of geography, Proceedings of the Royal Geographical Society and Monthly of Geography, 9, 3, s. 141-174.

-, 1902, Britain and the British Seas, D. Appleton and Co., New York.

-, 1904, The geographical pivot of history, The Geographical Journal, 23, London, s. 421-437.

-, 1919, Democratic Ideals and Reality, Holt, New York.

-, 1924, The Nations of the Modern World, t. II, G. Philips and Son, London.

-, 1943, The Round World and the Winning of the Peace, Foreign Affairs, 4, London.

-, 2009a, Geograficzna oś historii, opracował R. Potocki, Biblioteka Instytutu Geopolityki, t. IV, Częstochowa.

-, 2009b, Demokratyczne ideaty a rzeczywistość, tłumaczenie i opracowanie R. Domke, Przegląd Geopolityczny, 1, Częstochowa, s. 205-227.

Moczulski L., 1999, Geopolityka. Potęa w czasie i przestrzeni, Bellona, Warszawa.

Otok S., 2003, Geografia polityczna, Wydawnictwo Naukowe PWN, Warszawa.

Pobóg-Malinowski W., 1967, Najnowsza historia polityczna Polski 1914-1939, t. II, Wyd. Świderski, Londyn.

Rykiel Z., 2006, Podstawy geografii politycznej, Polskie Wydawnictwo Ekonomiczne, Warszawa.

Sloan G.R., 1999, Sir Halford Mackinder: the Heartland theory then and now, [w:] C.S. Gray, G.R. Sloan, Geopolitics, Geography and Strategy, Frank Cass, London, s. 15-38. 
Sykulski L., 2009, Geopolityka. Stownik terminologiczny, Wydawnictwo Naukowe PWN, Warszawa.

-, 2011, Ku nowej Europie: perspektywa zwiąku Unii Europejskiej i Rosji. Spojrzenie geopolityczne z Polski, Instytut Geopolityki, Częstochowa.

[Wpłynęło: październik 2010; poprawiono: luty 2011 r.]

\section{PIOTR EBERHARDT}

\section{HALFORD MACKINDER'S HEARTLAND CONCEPT}

The article is devoted to a presentation of the creative achievements of the British geographer Halford John Mackinder, in particular his most important geopolitical concept, i.e. the so-called "Heartland Theory". Prior to comment on the concept, the article presents the scientific vita of Mackinder. Origins and beginnings are detailed, as well as the academic and professional career. Mackinder was not only a Professor at the Universities in Oxford and London, but also politically active. Of particular importance was his role in 1919 as British High Commissioner to the army of Gen. Anton I. Denikin fighting against the Bolshevik forces. At that time he sought to coordinate the military actions of the Polish army and White Russian troops. In this context, his direct contacts with Polish statesmen J. Piłsudski, R. Dmowski and I. Paderewski are reported. The core part of the article then addresses Mackinder's famous Heartland Theory, which was deployed in three publications appearing in 1904, 1919 and 1943. In line with the basic precepts of this theory, the Heartland comprises areas in the central part of the Eurasian continent. These areas are surrounded by an inner zone, in particular encompassing Western Europe, the Middle East, India and China. The inner zone plus the Heartland form the "World Island", this being above all equivalent to the main body of the global continent. The World Island is surrounded by the World Ocean, over which isolated "islands" are scattered, these in fact being North and South America, Australia, and the islands of the Indian Ocean and Pacific. This view of the division of the globe became the starting point for the continental hypothesis proper, in which Mackinder argues that the state ruling the Heartland will also seek to rule the World Island, this in turn offering a gateway to global rule. Such reasoning led Mackinder to formulate his famous geopolitical doctrine summarised as: "the ruler of Eastern Europe commands the Heartland; the ruler of the Heartland commands the World Island; the ruler of the World Island commands the World".

The article then goes on to note that Mackinder was not a proponent of world domination by a continental empire. In fact, he warned that this highly probable variant was not optimal, carrying out a detailed analysis of the international situation that considered a continental power and a sea-borne power. Issues relevant to this are commented upon and explained in the article, and it is shown how, prior to the collapse of the Soviet Union, the evolution of geopolitical transformations had been taking place consistently with the scenario Mackinder elaborated. Only quite recently did this become outdated, and even then no harm to the significance of Mackinder's work is done, the British academic remaining one of the most prominent visionaries of classical geopolitics, who attempted to devise a consistent system as he sought laws underpinning the world's political evolution. 